\title{
PERANAN BUDAYA ORGANISASI DALAM MEWUJUDKAN GOOD UNIVERSITY GOVERNANCE (GUC) : SEBUAH IMPLIKASI SISTEM PENGENDALIAN INTERNAL DI POLITEKNIK NEGERI BANDUNG
}

\author{
Mia Rosmiati ${ }^{1)}$, Hastuti $^{2)}$, Deni Mulyana ${ }^{3)}$, Yanti Rufaedah ${ }^{4)}$ dan Benny Barnas ${ }^{5)}$ \\ 1,2,4,5 Jurusan Akuntansi, Politeknik Negeri Bandung \\ ${ }^{3}$ Jurusan Teknik Mesin, Politeknik Negeri Bandung \\ 1,2,3,4,5 Jalan Gegerkalong Hilir, Desa Ciwaruga, Bandung 40012 \\ E-mail: mia.rosmiati@polban.ac.id ${ }^{1)}$, hastuti@polban.ac.id ${ }^{2)}$,deni.mulyana@polban.ac.id ${ }^{3)}$,yrufaedah@gmail.com ${ }^{4)}$, \\ benny.barnas@polban.ac.id ${ }^{5)}$
}

\begin{abstract}
ABSTRAK
Tata kelola perguruan tinggi yang baik di masa globalisasi ini sudah menjadi tujuan atau cita-cita dari setiap institusi pendidikan tinggi yang ada di Indonesia, dan perwujudan dari cita-cita tersebut akan tercapai apabila perguruan tinggi sudah melaksanakan sistem pengendalian dengan baik. Penelitian ini bertujuan untuk menganalisis peranan budaya organisasi dalam mewujudkan Good University Governance $(G U G)$ melalui pelaksanaan kebijakan Sistem Pengendalian Internal (SPI) di Politeknik Negeri Bandung (POLBAN). Metode penelitian yang digunakan adalah deskriptif analisis dengan pendekatan kualitatif di mana penulis berupaya untuk memaparkan temuan yang diperoleh dari sumber data baik primer yang diperoleh melalui wawancara dengan informan maupun data sekunder berupa peraturan-peraturan mengenai sistem pengendalian, serta menganalisis kaitan antara dimensi yang ada dalam budaya organisasi dengan prinsip-prinsip yang terdapat dalam GUG. Hasil dari penelitian ini menunjukkan bahwa keberhasilan pelaksanaan SPI di POLBAN erat kaitannya dengan iklim atau budaya organisasi dari perguruan tinggi tersebut sehingga masih ada dimensi yang belum terlaksana secara benar dan menyeluruh. Apabila budaya yang dikembangkan dalam mengelola perguruan tinggi tersebut adalah budaya yang baik dan positif, maka cita-cita untuk mewujudkan tata kelola perguruan tinggi yang baik akan dengan mudah dicapai, demikian juga sebaliknya. Kesimpulan dari penelitian ini adalah perguruan tinggi perlu untuk mengembangkan budaya organisasi yang kondusif sehingga akan mendukung keberhasilan pelaksanaan sistem pengendalian internal di perguruan tinggi khususnya POLBAN yang pada akhirnya akan membantu perwujudan dari Good University Governance.
\end{abstract}

Kata Kunci : Perguruan Tinggi, Budaya Organisasi, Tata Kelola, Sistem Pengendalian, Prinsip GUG

\section{PENDAHULUAN}

Dalam melahirkan sumber daya manusia (SDM) yang unggul yang dapat bersaing secara sehat di berbagai bidang keilmuan. Hal ini sejalan dengan ciri pendidikan di era globalisasi dimana pendidikan menuntut perguruan tinggi untuk lebih terbuka dan transparan serta melakukan daya banding dan daya saing (benchmark) di tengah lingkungannya baik dalam skala lokal maupun global (Rusmini, 2015). Hal ini tentu saja memerlukan pengelolaan manajemen SDM dengan baik karena manajemen puncak pada suatu organisasi meyakini bahwa dengan memperbaiki praktik manajemen SDM akan meningkatkan produktivitas dan keuangan organisasi tersebut karena terdapat hubungan langsung di antara keduanya (Schuler \& Jackson, 2011). Politeknik Negeri Bandung (POLBAN) adalah perguruan tinggi yang sedang berupaya untuk mewujudkan Good University Governance $(G U G)$. Dengan demikian ada beberapa hal yang harus disiapkan oleh POLBAN agar dapat mencapai tujuan tersebut, salah satunya adalah
Pada abad ke 21 ini, perguruan tinggi berperan besar dengan melaksanakan kebijakan sistem pengendalian internal. Sistem pengendalian internal atau SPI ini memungkinkan POLBAN untuk dapat bekerja secara efektif dan efisien dengan memanfaatkan semua sumber daya yang dimiliki. Terdapat 3 (tiga) tujuan pengendalian internal, yaitu: 1) efektivitas dan efisiensi operasi; 2) reliabilitas/keandalan laporan keuangan; dan 3) kepatuhan terhadap hukum, peraturan dan kebijakan (COSO, 2013). Bentuk sinergitas antara kepatuhan terhadap kebijakan dengan sumber daya manusia di perguruan tinggi dipengaruhi oleh faktor penting yang selama ini tanpa disadari telah memberikan warna tersendiri terhadap arah tujuan sebuah lembaga pendidikan. Faktor tersebut adalah budaya organisasi yang akan memberikan gambaran lengkap mengenai kondisi sebuah perguruan tinggi dan upayanya dalam mencapai Good University Governance (GUG).

Penelitian dengan topik yang sama juga dilakukan oleh Zelmiyanti (2015) dengan hasil penelitian 
menunjukkan bahwa budaya organisasi dan sistem pengendalian internal berpengaruh signifikan positif terhadap pencegahan kecurangan di BPR Sumatera Barat sedangkan peran auditor internal tidak berpengaruh terhadap pencegahan kecurangan di BPR Sumatera Barat. Budaya organisasi berpengaruh signifikan positif terhadap pencegahan kecurangan melalui pelaksanaan sistem pengendalian internal di BPR Sumatera Barat. Peran auditor internal berpengaruh signifikan positif terhadap pencegahan kecurangan melalui pelaksanaan sistem pengendalian internal di BPR Sumatera Barat. Penelitian tersebut menggunakan metode yang berbeda dengan penelitian yang penulis lakukan.

Penelitian tentang keberhasilan penerapan sistem informasi tidak bisa diukur hanya dengan efisiensi dalam hal meminimalkan informasi biaya, namun keberhasilan harus diukur dengan budaya organisasi (Rahmawati, 2017). Hasil penelitian ini menunjukkan bahwa budaya organisasi dan pengendalian internal terhadap kualitas sistem informasi akuntansi manajemen sudah baik pada Dinas Penanaman Modal dan Pelayanan Terpadu Satu Pintu Kota Bandung. Data yang diperoleh dengan menyebarkan kuesioner kepada 38 responden. Budaya organisasi berpengaruh signifikan terhadap kualitas sistem informasi akuntansi manajemen dan pengendalian internal berpengaruh signifikan terhadap kualitas sistem informasi akuntansi manajemen.

Hasil penelitian yang dilakukan oleh Pituringsih (2016) mengenai budaya organisasi menunjukkan bahwa budaya organisasi berpengaruh terhadap kinerja manajerial koperasi Lombok Timur, komitmen organisasi berpengaruh terhadap kinerja manajerial koperasi Lombok Timur, penerapan good corporate governance berpengaruh terhadap kinerja manajerial koperasi Lombok Timur, dan sistem pengendalian intern tidak berpengaruh terhadap kinerja manajerial koperasi Lombok Timur.

Dari paparan tersebut hampir semua penelitian terdahulu dengan topik yang sama, menggunakan metode kuantitatif yang meneliti ada atau tidak adanya pengaruh dan mengukur seberapa besar pengaruh budaya organisasi terhadap tata kelola pemerintahan yang baik. Sedangkan kebaruan dari penelitian ini adalah bahwa konsep budaya organisasi dan sistem pengendalian internal akan lebih tepat jika menggunakan metode kualitatif karena dua konsep tersebut memerlukan kajian secara mendalam dan hasil penelitian tidak cukup valid jika ditampilkan dalam bentuk konfigurasi angka-angka saja, karena opini dari semua informan bisa dijadikan landasan untuk rekomendasi perbaikan kinerja sebuah organisasi melalui pengembangan budaya organisasinya yang dapat mewujudkan tata kelola perguruan tinggi yang baik. Selain itu karena lokus penelitian juga berbeda di mana objek yang diteliti adalah perguruan tinggi vokasi maka sistem nilai atau budaya yang dianut oleh POLBAN menjadi berbeda dengan budaya organisasi di luar institusi pendidikan. Apalagi perguruan tinggi vokasi mengharuskan setiap lulusannya menjadi sumber daya manusia yang siap bersaing di dunia industri apa pun, sehingga para dosen mempunyai keinginan mulia untuk mencurahkan segenap jiwa raga demi menghasilkan manusia yang berkualitas di mana hal ini sudah menjadi ciri khas budaya tenaga pendidik di POLBAN.

POLBAN sudah menerapkan kebijakan Sistem Pengendalian Internal (SPI) dalam upaya untuk mewujudkan tata kelola perguruan tinggi yang baik, namun dalam pelaksanaannya, prinsip-prinsip yang terdapat dalam SPI belum sepenuhnya dilaksanakan. Hal ini dikarenakan tidak semua personel terutama top manajemen yang memahami secara mendalam mengenai kebijakan sistem pengendalian ini, sehingga penerapan kebijakan sistem pengendaliannya masih bersifat sporadis dan tidak terdokumentasikan dengan baik di mana hal ini berdampak kepada penyusunan laporan kinerja institusi yang dipengaruhi oleh pelaksanaan sistem pengendalian internal. Kemudian budaya organisasi yang berkembang ikut berperan dalam keberhasilan atau kegagalan penerapan sistem pengendalian internal ini. Meskipun seperti yang telah diuraikan sebelumnya bahwa budaya setiap individu dosen di POLBAN itu menunjukkan sistem nilai yang baik akan tetapi hal ini tidak serta merta mendukung tercapainya tata kelola perguruan tinggi yang baik, jika dalam praktiknya tidak terdapat kerja sama yang harmonis antar individu.

Penelitian ini sangat penting dilakukan karena untuk mewujudkan Good University Governance sangattidak mudah. Perlu adanya suatu bentuk kolaborasi yang harmonis antara pihak manajemen (Top Level) dengan para pelaksana perguruan tinggi di lapangan (tenaga pengajar, tenaga administrasi, mahasiswa) untuk bersama-sama memahami dan melaksanakan sistem pengendalian internal (SPI) dengan baik dan benar sehingga SPI ini sebagai salah satu syarat untuk mewujudkan tata kelola perguruan tinggi yang baik, dapat terlaksana sesuai dengan prinsip-prinsipnya. Pemahaman akan diperoleh apabila manajemen mengadakan sosialisasi atau workshop mengenai sistem pengendalian internal ini yang ditujukan bagi seluruh personel yang ada di lingkungan institusi POLBAN termasuk para manajernya juga.

\section{RUANG LINGKUP}

Tata kelola perguruan tinggi yang baik akan dapat terlaksana apabila institusi pendidikan sudah melaksanakan sistem pengendalian internalnya secara menyeluruh dan hal ini dapat terwujud jika dalam 
pelaksanaannya mengembangkan atau menerapkan budaya organisasi yang baik.

Penelitian ini hanya akan membahas mengenai budaya organisasi dan pelaksanaan sistem pengendalian internal di POLBAN saja, mengingat budaya organisasi pada setiap perguruan tinggi berbeda-beda dan juga peraturan penerapan kebijakan sistem pengendalian internal di setiap perguruan tinggi berbeda pula tergantung dari standar yang akan digunakan oleh masing-masing perguruan tinggi tersebut.

Hasil dari penelitian ini akan memberikan informasi dan solusi yang dibutuhkan bagi para pemangku kebijakan di POLBAN tentang bagaimana seharusnya mengupayakan agar sistem pengendalian internal ini dapat dilaksanakan dengan baik dan benar serta bagaimana cara untuk mengembangkan budaya organisasi yang mendukung terlaksananya SPI tersebut. Dengan demikian maka POLBAN dapat diperhitungkan baik oleh industri maupun oleh instansi pemerintah serta akan diminati oleh masyarakat luas dan dapat mewujudkan tata kelola perguruan tinggi yang baik.

\section{BAHAN DAN METODE}

Berikut dijabarkan bahan dan metode yang menjadi kajian dalam penelitian ini

\subsection{Budaya Organisasi}

Budaya organisasi merupakan unsur lain yang menjadi perekat hubungan sosial yang memadukan suatu organisasi sehingga bersatu. Budaya merupakan lingkungan (internal) sehari-hari yang terlihat dan dirasakan oleh mereka yang bekerja di dalamnya. Budaya juga menggambarkan bagaimana sumber daya manusia belajar untuk melakukan sesuatu dalam organisasi, ini merupakan bagaimana kebiasaan SDM di suatu perusahaan dan apa yang sebenarnya terjadi di perusahaan tersebut. Budaya memberi setiap organisasi ciri dan arti (Rahmawati, 2017)

\subsection{Peranan dan Fungsi Budaya Organisasi}

Budaya menjalankan sejumlah fungsi di dalam sebuah organisasi. Pertama, budaya mempunyai suatu peran menetapkan tapal batas; artinya, budaya menciptakan pembedaan yang jelas antara satu organisasi dan yang lain. Kedua, budaya membawa suatu rasa identitas bagi anggota-anggota organisasi. Ketiga, budaya mempermudah timbulnya komitmen pada sesuatu yang lebih luas daripada kepentingan diri pribadi seseorang. Keempat, budaya itu meningkatkan kemantapan sistem sosial. Budaya merupakan perekat sosial yang membantu mempersatukan organisasi itu dengan memberikan standar-standar yang tepat untuk apa yang harus dikatakan dan dilakukan oleh para karyawan (Robbins, 2017).

\subsection{Dimensi Budaya Organisasi}

Dimensi budaya organisasi adalah : 1) Inovasi dan pengambilan risiko. Sejauh mana para karyawan didorong untuk inovatif dan mengambil risiko. 2) Perhatian ke rincian. Sejauh mana para karyawan diharapkan memperlihatkan presisi (kecermatan), analisis, dan perhatian kepada rincian. 3) Orientasi hasil. Sejauh mana manajemen memusatkan perhatian pada hasil bukannya pada teknik dan proses yang digunakan untuk mencapai hasil itu. 4) Orientasi orang. Sejauh mana keputusan manajemen memperhitungkan efek hasil-hasil pada orang-orang di dalam organisasi itu. 5) Orientasi tim. Sejauh mana kegiatan kerja diorganisasikan sekitar tim-tim, bukannya individuindividu. 6) Keagresifan. Sejauh mana orang-orang itu agresif dan kompetitif dan bukannya santai-santai. 7) Kemantapan. Sejauh mana kegiatan organisasi menekankan dipertahankannya status quo daripada pertumbuhan (Robbins, 2017)

\subsection{Good University Governance}

Good University Governance ialah suatu konsep pada penyelenggaraan manajemen pembangunan yang solid dan bertanggung jawab sejalan dengan demokrasi dan pasar yang efisien, penghindaran salah alokasi dan investasi yang langka dan pencegahan korupsi baik secara politik maupun administratif, menjalankan disiplin anggaran serta penciptaan legal and political framework bagi tumbuhnya aktivitas kewiraswastaan.(World Bank, 2002). Konsep tersebut apabila diterapkan dalam manajemen perguruan tinggi akan mempunyai prinsip-prinsip GUG sebagai berikut:

1. Transparansi

Transparansi, yaitu tentang sejauh mana kebijakan regulasi, program, kegiatan dan anggaran PT diketahui, dan dipahami oleh ccivitas akademik sehingga mereka dapat berpartisipasi secara aktif.

2. Pengorganisasian

Pengorganisasian, yaitu tentang sejauh mana pimpinan PT mampu menerapkan berbagai prinsip pengorganisasian, seperti menetapkan tata hubungan kerja, rincian tugas pokok, fungsi/wewenang serta melakukan directing (pengarahan).

3. Partisipasi

Partisipasi, yaitu tentang sejauh mana proses pengambilan keputusan strategis PT melibatkan secara partisipatif stakeholders eksternal dan internal, sehingga stakeholders dapat mendukungnya secara aktif.

4. Responsivitas

Responsivitas, yaitu tentang sejauh mana kebijakan, regulasi, dan pengalokasian anggaran mendapat dukungan dan tanggapan positif dari ccivitas akademik. Efisiensi dan Efektivitas, yaitu tentang 
seberapa besar upaya pimpinan PT untuk membuat ccivitas akademik paham, dan dapat memberi komitmen yang tinggi terhadap kebijakan, regulasi, dan program yang ditetapkan oleh pimpinan.

5. Akuntabilitas

Akuntabilitas, yaitu tentang seberapa jauh tingkat pertanggungjawaban pimpinan PT dalam menjalankan tugasnya.

6. Kepemimpinan

Kepemimpinan, yaitu tentang sejauh mana kepemimpinan PT mampu menciptakan suasana kerja yang kondusif, dan mampu memotivasi civitas akademik untuk bekerja secara produktif dalam mencapai visi dan misi PT. Perlu dikemukakan bahwa unsur-unsur utama tersebut tidak dipenuhi secara terpisah, melainkan harus dipenuhi secara integratif (World Bank, 2011)

\subsection{Sistem Pengendalian Intern}

Sistem Pengendalian Internal adalah proses yang integral pada tindakan dan kegiatan yang dilakukan secara terus-menerus oleh pimpinan dan seluruh pegawai untuk memberikan keyakinan memadai atas tercapainya tujuan organisasi melalui kegiatan yang efektif dan efisien, keandalan pelaporan keuangan, pengamanan aset negara, dan ketaatan terhadap peraturan perundangundangan (PP No. 60 Tahun 2008)

SPIP yang dimuat dalam PP No. 60 Tahun 2008 merujuk pada konsep pengendalian internal yang dikemukakan oleh Committee of Sponsoring Organizations (COSO) terdiri dari lima komponen utama, yaitu lingkungan pengendalian, penilaian risiko, kegiatan pengendalian, informasi dan komunikasi, serta pemantauan (Coso, 2013).

\subsection{Metode Analisis}

Penelitian ini menggunakan deskriptif kualitatif sehingga data akan dianalisis dengan menggunakan kemampuan instrumen penelitian dalam menginterpretasikan informasi secara luas dan akurat (Sugiyono, 2017). Dalam penelitian kualitatif terdapat 3 tahapan yang penting (Moleong, 2017). Adapun tahapannya adalah sebagai berikut :

1. Tahap pra-lapangan, yaitu orientasi yang meliputi kegiatan penentuan fokus, penyesuaian paradigma dengan teori di mana peneliti mempelajari konsep dan peraturan-peraturan yang mendukung penelitian ini.

2. Tahap kegiatan lapangan, tahap ini meliputi pengumpulan data-data yang terkait dengan fokus penelitian yaitu tentang budaya organisasi dan penerapan sistem pengendalian internal.

3. Tahap analisis data, tahap ini meliputi kegiatan mengolah dan mengorganisir data yang diperoleh melalui observasi partisipan, wawancara mendalam dan dokumentasi, setelah itu dilakukan penafsiran data sesuai dengan konteks permasalahan yang diteliti. Selanjutnya dilakukan pengecekan keabsahan data dengan cara triangulasi data.

\section{PEMBAHASAN}

Berikut ini adalah paparan mengenai hasil penelitian beserta pembahasannya yang terbagi ke dalam 3 sub bagian.

\subsection{Peranan Budaya Organisasi dalam mewujudkan Good University Governance (GUG)}

Budaya organisasi yang berkembang di POLBAN sering kali tidak mempunyai pijakan yang jelas dikarenakan terjadinya beberapa kali pergantian personil pada level top manajemen. Pergantian dilakukan berdasarkan pemilihan pimpinan pucuk atau direktur sebagai akibat telah berakhirnya masa jabatan direktur pada periode sebelumnya. Pada saat pergantian pimpinan pucuk, maka akan serta merta terjadi pergantian personil pada level di bawah direktur. Hal ini merupakan suatu hal yang wajar terjadi, karena seorang pemimpin akan memilih para pembantunya yang sesuai dengan semangat dan visi misi yang diemban oleh pemimpin tersebut, sehingga seorang pemimpin akan memilih bawahan yang akan membantu terselenggaranya organisasi dengan baik dalam upaya mewujudkan tujuannya tersebut. Berdasarkan olah data yang dilakukan peneliti maka diperoleh hasil sebagai berikut:

1. Dimensi inovasi dan pengambilan risiko di mana sebagai indikatornya adalah tingkat organisasi mendorong karyawan bersikap inovatif dan berani menghadapi tantangan kerja. Data memberikan informasi bahwa manajemen POLBAN senantiasa memberikan dorongan kepada para sumber daya manusia yang ada di lingkungan Polban untuk berkarya dan berani mengambil tantangan pekerjaan yang akan membuat sumber daya di lingkungan POLBAN mempunyai value yang tinggi dan mampu menghadapi era 4.0 sesuai dengan yang dicanangkan oleh pemerintah. Hal ini dilakukan dengan diberikannya insentif bagi seluruh dosen yang dapat menghasilkan luaran penelitian dengan standar jurnal/prosiding bereputasi.

2. Dimensi perhatian pada rincian di mana sebagai indikatornya adalah tingkat ketelitian pada rincian yang dituntut oleh organisasi sesuai kondisi yang nyata, membuat manajemen POLBAN melakukan tindakan antisipasi dalam meminimalisir segala kemungkinan yang dapat muncul/terjadi dalam setiap pengambilan keputusan. Hal ini dilakukan dengan memaksimalkan peran Satuan Pengawas Internal (SPI) sebagai bagian dari organ institusi POLBAN untuk melakukan review secara mendalam terhadap suatu kegiatan/kebijakan yang 
memerlukan adanya suatu ketelitian dalam pelaksanaannya.

3. Dimensi orientasi hasil sebagai indikatornya adalah tingkat seberapa jauh manajemen fokus pada hasil daripada teknik dan proses yang dipakai untuk mencapai tujuan. Dalam melaksanakan sebuah kebijakan, yang dijadikan titik perhatian adalah bagaimana luaran dari aktivitas yang sudah dilakukan terutama yang berkaitan dengan peningkatan kualitas sumber daya yang ada sehingga teknik dan proses sedikit terabaikan. Walaupun pada akhirnya tujuan dapat tercapai sesuai target namun ada beberapa catatan yang harus diperhatikan oleh manajemen.

4. Dimensi orientasi orang sebagai indikatornya adalah tingkat seberapa jauh keputusan manajemen memperhitungkan dampaknya pada para individu di dalam organisasi. Manajemen dalam membuat sebuah kebijakan tentunya akan memperhitungkan dampak positif dan dampak negatif yang akan diterima oleh seluruh personel, sehingga manajemen berupaya untuk membuat keputusan dengan mengedepankan asas fairness dalam pelaksanaannya dan berupaya agar tidak ada satu pihak pun yang akan dirugikan atas keputusan yang diambil.

5. Dimensi orientasi team sebagai indikatornya adalah tingkat seberapa jauh aktivitas pekerjaan diorganisasikan kepada tim daripada individual. Hal ini dilakukan untuk melibatkan semua personel yang ada di lingkungan POLBAN. Setiap dosen mempunyai kewajiban Tridarma Perguruan Tinggi yang berlaku bagi semua dosen baik dosen junior maupun dosen senior. Jika tidak menjalankan budaya orientasi kepada tim, maka para dosen junior akan berlari jauh meninggalkan para seniornya untuk melaksanakan semua kewajiban yang dibebankan kepada setiap individu. Untuk itulah manajemen POLBAN begitu menekankan budaya kerja yang berorientasi kepada tim, agar semua personel mampu untuk memenuhi semua kewajiban tridarmanya.

6. Dimensi keagresifan sebagai indikatornya adalah tingkat seberapa jauh para individu agresif dan kompetitif daripada bersikap santai dan apa adanya. Hal ini senada dengan dimensi yang pertama yaitu inovatif dan berani mengambil risiko pekerjaan karena jika sikap yang dipunyai oleh para personel di POLBAN adalah "easy going" maka POLBAN akan tertinggal sangat jauh dibandingkan dengan perguruan tinggi lainnya. Sehingga manajemen mengupayakan berbagai kebijakan yang akan memacu dan menimbulkan semangat kerja yang tinggi di antara semua sumber dayanya.
7. Dimensi kemantapan sebagai indikatornya adalah tingkat sejauh mana kegiatan organisasi menekankan posisi status quo daripada perubahan organisasi. Hal ini dilakukan oleh manajemen POLBAN dalam upaya memberikan atau menunjukkan identitas diri dari institusi POLBAN sendiri. POLBAN sebagai perguruan tinggi vokasi mempunyai visi misi yang menunjukkan kekhasan dan komitmen yang terus dipertahankan untuk mencapai tujuan organisasi. Sehingga POLBAN mantap untuk bersaing dengan perguruan tinggi lainnya dan siap untuk melaksanakan tata kelola perguruan tinggi yang baik.

\subsection{Pelaksanaan Sistem Pengendalian Internal}

Hasil dari penelitian mengenai sistem pengendalian internal ini ini menunjukkan bahwa manajemen POLBAN yang baru yang dilantik pada pertengahan tahun 2019 yang lalu, mempunyai komitmen untuk membawa institusi POLBAN menuju perguruan tinggi yang akan mewujudkan Good University Governance. Hal ini ditunjukkan dengan hasil pengolahan dan analisis data mengenai pelaksanaan prinsip-prinsip sistem pengendalian internal di lingkungan POLBAN sebagai berikut :

1. POLBAN telah melaksanakan praktik pengendalian intern, namun pelaksanaan pengendalian intern tidak terdokumentasi dengan baik, dokumentasi penyelenggaraan SPIP masih kurang (bersifat sporadis dan tidak konsisten). Hal ini kurang sejalan dengan prinsip akuntabilitas dalam konsep GUG, di mana pertanggungjawaban akan semua aktivitas/kegiatan yang telah dilakukan akan mempunyai nilai apabila terdapat provelevidence sebagai tolak ukur jika suatu kegiatan yang didasari oleh kebijakan, sudah selesai dilaksanakan.

2. Pengendalian masih sangat tergantung pada kemauan/inisiatif individu tertentu. Hal ini kurang sejalan dengan prinsip partisipasi dalam konsep GUG. Suatu kebijakan akan dapat terlaksana dengan baik apabila mendapat dukungan penuh dari berbagai elemen organisasi, baik itu secara individu maupun kelompok. Sehingga dibutuhkan peran aktif dari semua pihak yang berada dalam suatu organisasi.

3. Pelaksanaan dan penilaian pengendalian intern sangat tergantung pada individu tertentu (individu kunci) dan belum melibatkan semua unit organisasi. Hal ini kurang sejalan dengan prinsip transparansi dalam konsep GUG. Penilaian dalam pelaksanaan sistem pengendalian internal dilakukan oleh pihak yang telah ditentukan sesuai peraturan yang berlaku, sehingga internal POLBAN tidak dapat melakukan self asssesment untuk mendapatkan penilaian 
maturitas yang baik. Nilai yang di berikan pun akan sesuai dengan kondisi real institusi.

4. Sudah mulai timbul kesadaran pegawai untuk melaksanakan tanggung jawab masing-masing. Hal ini sejalan dengan prinsip responcivitas dalam konsep GUG. Kesadaran akan pentingnya sebuah tanggung jawab yang harus dimiliki baik oleh setiap individu maupun oleh sebuah tim/unit kerja di POLBAN akan memberikan dampak yang positif dalam upaya mewujudkan tata kelola perguruan tinggi yang baik. Hal ini sudah seharusnya bisa dipertahankan dan dijadikan sebagai "budaya" yang baik bagi institusi POLBAN di mana budaya organisasi yang baik akan mendukung terlaksananya kebijakan sistem pengendalian internal yang pada akhirnya akan menghantarkan POLBAN menjadi sebuah perguruan tinggi yang dapat mencapai tujuan GUG.

5. Efektivitas pengendalian belum dievaluasi sehingga banyak terjadi kelemahan yang belum ditangani secara memadai. Evaluasi mutlak perlu dilakukan oleh sebuah organisasi dalam menjalankan aktivitas kesehariannya. Hal ini sejalan dengan prinsip pengorganisasian dalam konsep GUG. Untuk mengetahui potensi yang dimiliki oleh sebuah organisasi, dalam hal ini adalah POLBAN, perlu dilakukan suatu self assesment yang bisa dilakukan dengan menggunakan analisis SWOT. Analisis ini akan menguraikan potensi kekuatan, kelemahan, kesempatan dan ancaman yang dipunyai oleh POLBAN. Sehingga dengan mengetahui berbagai potensi sebuah organisasi maka akan dengan mudah melakukan evaluasi dari suatu kebijakan yang diterapkan yang dalam hal ini adalah kebijakan sistem pengendalian internal, karena apabila kita berbicara tentang bagaimana memanjemen sebuah organisasi maka yang akan menjadi tolak ukur adalah fungsi-fungsi dalam manajemen yaitu planning, organization, actuating dan controling serta evaluating.

6. Tindakan manajemen untuk menyelesaikan permasalahan pengendalian belum menjadi prioritas dan belum konsisten. Hal ini kurang sejalan dengan prinsip kepemimpinan dalam konsep GUG. Seperti yang telah kita pahami bersama bahwa keberhasilan sebuah organisasi dalam mencapai tujuannya terletak pada bagaimana pimpinan organisasi tersebut menjalankan roda pemerintahan dengan baik. Seorang pemimpin diharapkan mampu untuk tampil menjadi seorang pemimpin yang adil, berorientasi kepada kepentingan para anggotanya pada saat akan mengambil sebuah keputusan.

\section{KESIMPULAN}

Berdasarkan uraian pada pembahasan, POLBAN masih mengembangkan budaya individualistis dan kurang mengembangkan budaya kerja sama dalam tim sehingga pelaksanaan praktik pengendalian internal pun dilakukan secara parsial dan belum menyeluruh, karena ada poin-poin yang masih belum sesuai dengan prinsipprinsip dalam konsep GUG. Untuk mewujudkan terlaksananya tata kelola pendidikan yang baik, salah satunya adalah semua elemen pendukung kebijakan harus terintegrasi dan hal itu dapat tercapai jika terdapat kerja sama antara individu dengan tim.

Maka dari itu top manajemen menyatakan bahwa akan ada perbaikan mengenai pelaksanaan pengendalian internal ini secepat mungkin mengingat POLBAN juga harus menyusun laporan kinerja instansi pemerintah (LAKIP) di mana laporannya itu akan mempunyai kualitas yang baik apabila sistem pengendalian internalnya sudah terlaksana dengan baik pula . Top manajemen juga akan lebih mengembangkan budaya organisasi ke arah yang lebih baik agar tercipta sinergitas antar invidu dengan mengedepankan prinsip kerja sama dalam satu tim yang solid serta manajemen juga akan mendorong individu agar mempunyai daya kreativitas yang tinggi yang akan memunculkan kesadaran pegawai yang lebih baik untuk melaksanakan tanggung jawab masing-masing.

\section{SARAN}

Manajemen POLBAN sebaiknya mengadakan sosialisasi mengenai sistem pengendalian internal yang ditujukan bagi para pemangku kepentingan, agar sistem pengendalian internal ini dapat lebih dipahami dan terlaksana dalam setiap aktivitas penyelenggaraan pendidikan di institusi. Selain sosialisasi diharapkan semua manajemen di level atas, untuk bisa mengaplikasikan sistem pengendalian internal pada setiap bidang atau unit kerja secara terintegrasi sehingga memudahkan dalam proses pelaksanaan setiap kegiatan dan juga memudahkan dalam proses evaluasinya.

Manajemen POLBAN sebaiknya memberikan perhatian lebih terhadap perencanaan sumber daya manusia agar dapat mendorong pencapaian tujuan good university governance dengan lebih cepat dan lebih baik.

Manajemen POLBAN juga diharapkan dapat mengadopsi budaya organisasi yang positif yang dikembangkan oleh institusi pendidikan lainnya sehingga perlu mengadakan benchmark atau studi banding untuk melihat sejauh mana budaya organisasi mempengaruhi pelaksanaan tata kelola perguruan tinggi yang akan mendukung terwujudnya tata kelola perguruan tinggi yang baik.

\section{DAFTAR PUSTAKA}

Committee of Sponsoring Organization of Treadway Commision (COSO). 2013. Internal Control Integrated Frame Work (Codification). New York: AICPA.

Robbins, Stephen \& Judge A. Timothy, 2017. Organizational Behavior (Edisi 16). Jakarta: Salemba Empat 
Moleong, Lexy J., 2017, Metodologi Penelitian Kualitatif, (Edisi Revisi) Bandung: Remaja Rosdakarya.

Pituringsih, E. Herwanti, T. Busaini. Pengaruh Budaya Organisasi, Komitmen Organisasi, Penerapan GCG dan Sistem Pengendalian Internal terhadap Kinerja Manajerial. Jurnal Ekonomi, Manajemen dan Akuntansi (Assets), VI (1), 2016

Rahmawati, R, Pengaruh Budaya Organisasi dan Pengendalian Internal terhadap Kualitas Sistem Informasi Akuntansi Manajemen. Jurnal Akuntansi, Audit dan Sistem Informasi Akuntansi (JASa), I (2), 2017.

Rusmini,.2015. Peningkatan Mutu Lembaga Pendidikan Tinggi Melalui Pengembangan Sumber Daya
Manusia, Jurnal Kependidikan Islam, IAIN Sulthan Thaha Saifudin : Jambi,

Schuler, Randall S., Jackson, Susan E., 2011. Manajemen Sumber Daya Manusia Edisi 10, Jakarta: Salemba Empat

Sugiyono, 2017, Metodologi Penelitian Kuantitatif, Kualitatif dan $R \& D$, Bandung : Alfabeta. Intervening, Jurnal Akuntansi Keuangan dan Bisnis, VIII (11), 67-76, 2015

World Bank, 2011, Good Governance. Washington: The World Bank.

Zelmiyanti, R., Anita, L., Pengaruh Budaya Organisasi dan Peran Auditor Internal terhadap Pencegahan Kecurangan dengan Pelaksanaan Sistem Pengendalian Intern sebagai Vari 